\title{
Central retinal artery occlusion and central retinal vein occlusion in contralateral eye
}

Oclusão da artéria central da retina com oclusão da veia central em olho contralateral

Felipe Beltrão de Medeiros ${ }^{1}$ (1), Isabela Porto Silva Costa ${ }^{2}$ (D), João Pedro Vedovelli de Araujo ${ }^{3}$ (1), Jaqueline Cordeiro de Souza ${ }^{4}$ (i), Hilton Arcoverde Gonçalves de Medeiros ${ }^{4}$ (b)

1 Universidade Estadual Paulista "Júlio de Mesquita Filho", Botucatu, SP, Brazil. ${ }^{2}$ Hospital de Base do Distrito Federal, Brasília, DF, Brazil. ${ }^{3}$ Faculdade São Leopoldo Mandic, Araras, SP, Brazil. ${ }^{4}$ Clínica de Olhos Dr. João Eugênio, Brasília, DF, Brazil.

Keywords:

Retinal diseases; Retinal artery; Retinal vein; Ischemia

Descritores:

Doenças retinianas; Arteria retiniana; Veia retiniana; Isquemia

Received on: Jan 6, 2021

Accepted on: Aug 11, 2021

Corresponding author: Hilton Arcoverde Gonçalves de Medeiros Clínica de Olhos Dr. João Eugênio SHIS QI 05, conjunto 9, casa 2 Zip code: 71615-090 - Brasília, DF, Brazil

E-mail: hilton@hiltonmedeiros.com.br

Institution: Clínica de Olhos Dr. João Eugênio, Brasília, DF, Brazil.

Conflict of interest: no conflict of interest.

Financial support: the authors received no financial support for this work.

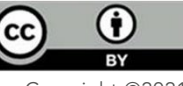

Copyright (C2021

\section{ABSTRACT}

The case of a 55-year-old male who presented central retinal vein occlusion with marked macular ischemia in left eye is reported. Despite the intervention with sustained-release dexamethasone polymer injection and other clinical measures, the visual acuity was severely reduced in left eye. After 8 months, he returned to the emergency with acute visual loss of 2 hours of progression in right eye due to a central retinal artery occlusion, sparing only the territory of the cilioretinal artery. Patient underwent clinical maneuvers with anterior chamber paracentesis and intravenous injection of tissue plasminogen activator. Fluorescein angiography immediately after the procedures showed recanalization, but despite arterial vasodilation, no complete recanalization was observed after 24 hours. The patient developed retinal atrophy.

\section{RESUMO}

Apresenta-se o caso de um paciente do sexo masculino, de 55 anos, com oclusão de veia central retiniana com acentuada isquemia macular em olho esquerdo. Apesar da intervenção com injeção de polímero de liberação lenta de dexametasona e outras medidas clínicas tomadas, ele evoluiu com severa baixa da acuidade visual em olho esquerdo. Após 8 meses, retornou à emergência com perda visual aguda de 2 horas de evolução em olho direito devido à oclusão de artéria central retiniana, poupando apenas o território da artéria ciliorretiniana. O paciente foi submetido a manobras clínicas, com paracentese de câmara anterior e injeção endovenosa de ativador do plasminogênio tecidual. A angiografia fluoresceínica imediatamente após as manobras mostrou recanalização, porém, a despeito do vasodilatador arterial, não foi observada completa recanalização com 24 horas. O paciente evoluiu com atrofia retiniana. 


\section{INTRODUCTION}

Central retinal artery occlusion (CRAO) presents with sudden, severe, painless and usually unilateral loss of vision. Analogous to ischemic cerebral stroke, it is often caused by thromboembolic events due to ipsilateral carotid artery disease, primarily related to atherosclerotic plaques. ${ }^{(1)}$

It is one of the ocular conditions requiring urgent treatment, since patients may have comorbidities and the associated mortality rate is high. ${ }^{(2,3)}$ Obstruction reveals ischemic whitening at the posterior pole, which may spare the papillomacular bundle in cases where the cilioretinal artery irrigates this region..$^{(4,5)}$

Regarding venous occlusion, an increase in retinal venous pressure is expected and blood flow is reduced. The mechanism of obstruction is not well established, but it is believed to be caused by either thrombosis or mechanical compression in the lamina cribosa. ${ }^{(6)}$ Some findings, such as intraretinal hemorrhages and vessel tortuosity, are characteristic of this condition. ${ }^{(6,7)}$

In both cases, impaired visual acuity is closely linked to severity of ischemia and foveal involvement, and sudden loss of vision is more common. . $^{(1,7)}$

The present study aimed to elucidate a clinical case of a patient presenting central retinal vein occlusion (CRVO) and CRAO in the contralateral eye.

\section{CASE REPORT}

A 55-year-old white hypertensive male patient on bisoprolol $5 \mathrm{mg} /$ day and losartan $50 \mathrm{mg} /$ day, presented visual acuity (VA) of 20/20 in the right eye (RE) and 20/400 in the left eye (LE). The low VA was secondary to a CRVO in LE with severe ischemic component one week before (Figure 1). Treatment was initiated with intravitreal injection of Ozurdex ${ }^{\circledR}$, peripheral vasodilator, ocular hypotensive agent, and retinal photocoagulation in ischemic areas, according to fluorescein angiography (AGF).

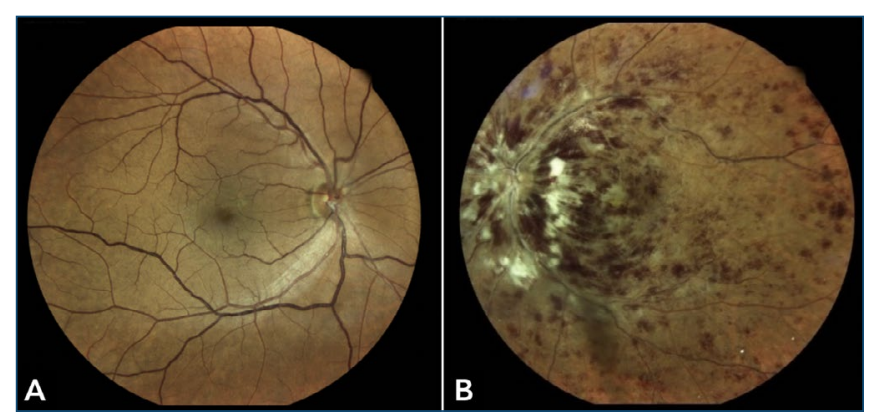

Figure 1. Initial state of right and left eye showing central retinal vein occlusion.
Laboratory tests showed only an increase in low-density lipoprotein (LDL; $295 \mathrm{mg} / \mathrm{dL}$ ), with no other major changes. Carotid Doppler showed bilateral atheroma with no hemodynamic changes. In addition, blood pressure of 190/110 mmHg was measured due to poor adherence to systemic antihypertensive treatment. Losartan was replaced by clonidine hydrochloride $0.1 \mathrm{mg}$, and rosuvastatin $20 \mathrm{mg}$ was initiated, which normalized blood pressure control to $130 / 80 \mathrm{mmHg}$.

Despite the measures taken, the patient evolved with severe low VA secondary to retinal atrophy, as confirmed by the optical coherence tomography (OCT) (Figure 2).

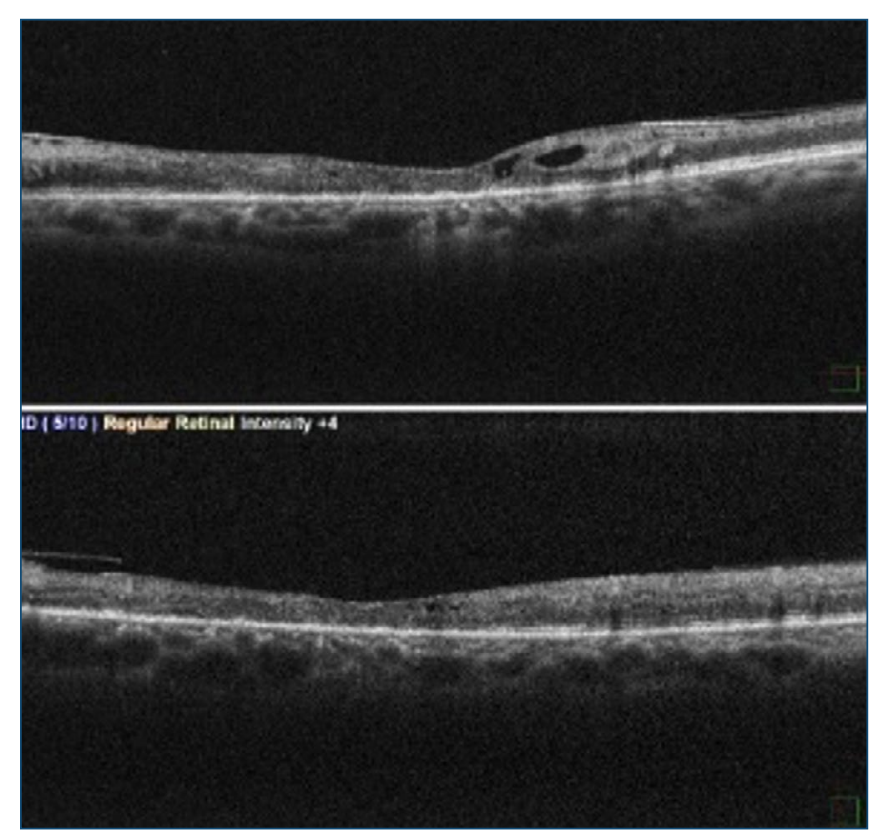

Figure 2. Optical coherence tomography of the left eye showing severe retinal atrophy.

After 8-month progression, the patient came to the emergency room complaining of loss of VA in the RE, two hours before. The examination revealed CRAO (Figure 3), with preservation of the territory of cilioretinal artery. At this time, ocular paracentesis was performed, followed by compression/decompression massage on the eyeball, endovenous tissue plasminogen activators (tPA) injection, arterial vasodilator (Sustrate ${ }^{\circledR}$ ), and fundus fluorescein angiography (FFA) to verify arterial flow, in which it was possible to observe there was already arterial flow (Figure 3). After 24 hours, the condition improved, but CRAO persisted (Figure 4).

Due to time elapsed, it was decided to observe the risk of neovascular glaucoma and order screening laboratory tests for rheumatic and hematological diseases; the results were negative. At this time, it was also found the patient was not regularly using antihypertensive medication. 


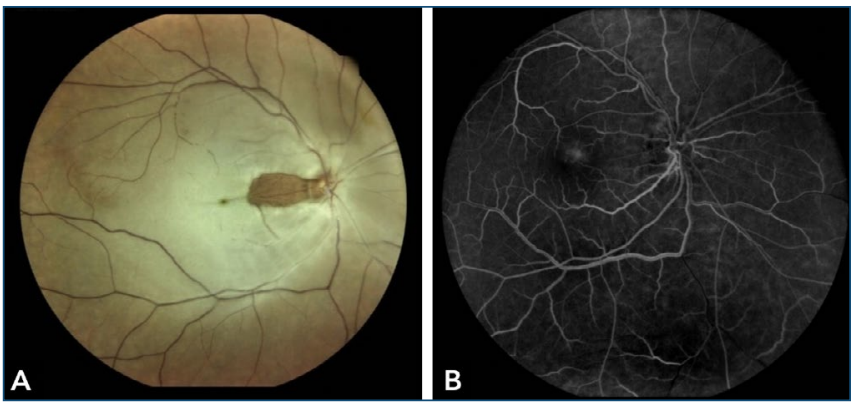

Figure 3. Central retinal artery occlusion in early right eye and fluorescein angiography proving the existence of arterial flow.

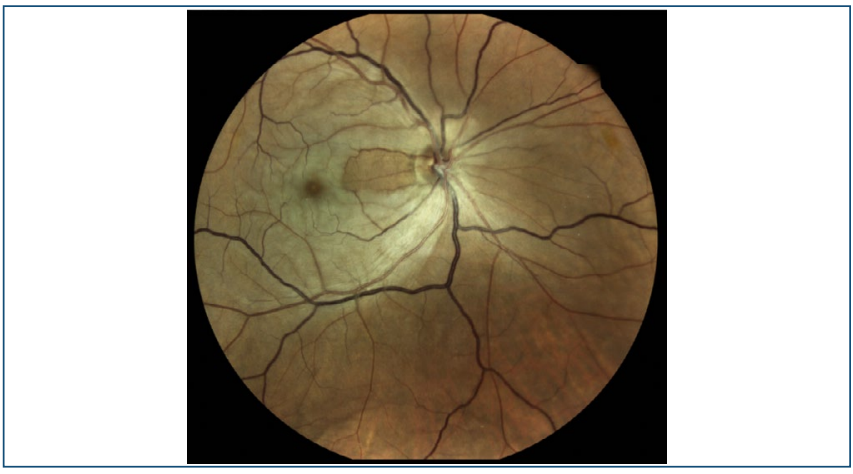

Figure 4. 24-hour aspect, which shows a persistent ischemic condition, despite vascularization on the previous day.

In 6-month follow-up of the condition in RE, there was a complete vascular recanalization, with no glaucoma associated, but atrophy of the retinal inner layers on OCT (Figure 5).

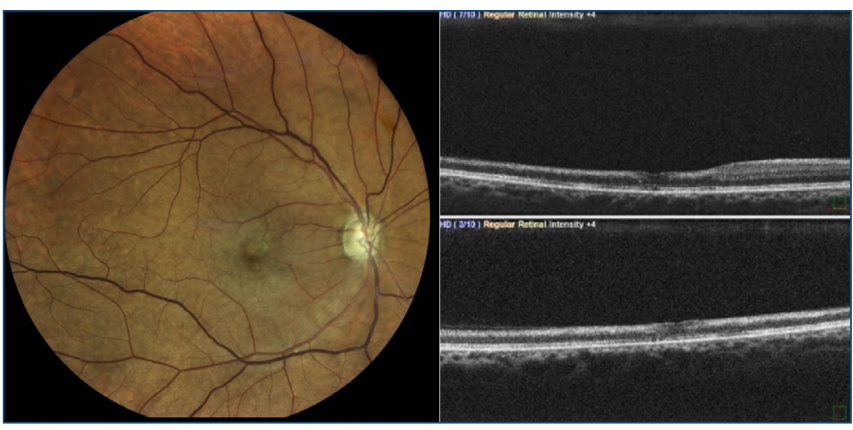

Figure 5. Final aspect showing retinal atrophy, except for the area of the cilioretinal artery.

\section{DISCUSSION}

As from the initial description by Graefes, in $1859,{ }^{(8)}$ CRAO has been one of the few ocular conditions absolutely urgent, usually accompanied by comorbidities, and a high five-year mortality rate. ${ }^{(2,3)}$

Arterial occlusion is a rare condition, with an estimated incidence of 8.5 cases per 100,000 inhabitants, usually secondary to fatty embolus from the internal carotid artery, and it presents as sudden and painless visual field loss. ${ }^{14}$

6) The CRVO has an estimated prevalence of $0.4 \%$ and its pathophysiology has not been fully understood yet. It is believed the condition is due to thromboembolic occlusion in the region of the lamina cribosa, but can also be caused by mechanical compression of the vein at the same place, secondary to increased intraocular pressure. ${ }^{(6)}$ Fundus examination shows intraretinal hemorrhages (dot blot and flame-shaped) in the four quadrants, associated with increased venous caliber and tortuosity. ${ }^{(6)}$ The prognosis is related to the occurrence of vision loss due to macular edema, intraretinal hemorrhage, and ischemia, leading to neovascularization..$^{(9)}$

The control of factors associated with arterial occlusion may be crucial, preventing the onset of cerebral ischemic disease or ischemic cardiomyopathy, ${ }^{(2,5,10)}$ which may appear in the first and second week, when upon examination. ${ }^{(8)}$ Thus, rapid and accurate diagnosis of the condition involved is important to prevent mortality. Classical retinal findings on fundus examination include retinal edema, cherry red spot, retinal arteriolar attenuation, and slow segmental blood flow in retinal arterioles. ${ }^{(4,5)}$

Based on etiology and characteristics, CRAO can be classified into four types: non-arteritic CRAO; non-arteritic CRAO with cilioretinal artery sparing; transient non-arteritic CRAO; and arteritic CRAO. ${ }^{(5)}$

The incidence of presence of cilioretinal artery is variable, and may reach up to 33\%. ${ }^{(4)}$ In the present case, the final acuity associated with tubular vision occurred largely due to blood flow maintained by irrigation of this artery. The presence of this artery is a positive prognostic factor. ${ }^{(4)}$

Ocular compression/ decompression and paracentesis maneuvers as first measures in treatment of $\mathrm{CRAO}$, in addition to use of pharmacological agents, such as urokinase and streptokinase, have been reported, as well as intravenous tPA. ${ }^{(11)}$ All of these models are employed at the interval between occlusion and treatment initiation, which should not exceed 6 hours. ${ }^{(11)}$

Central retinal vein occlusion can be classified according to tissue perfusion status by fluorescein angiography (FA) as ischemic or non-ischemic. ${ }^{(6,7,9)}$ Moreover, it is well known that over $75 \%$ of CRVOs are non-ischemic, and $34 \%$ of those cases converted to ischemic form during follow-up. Furthermore, up to 60\% of eyes with ischemic CRVO developed neovascularization, with neovascular glaucoma developing in some cases. ${ }^{\left({ }^{9}\right)}$

Systemic findings found in CRAO combined with CRVO include diabetes, hypertension, dyslipidemia, as well as inflammatory, coagulation and tumoral disorders. ${ }^{(12,13)}$ Recently, high factor VIII indices have been associated with venous thromboembolism in cases of combined venous and arterial 
occlusions, ${ }^{(13)}$ but they were not present in this patient. Carotid Doppler ultrasound and echocardiography are important ancillary tests to order and elucidate etiology of the cases. ${ }^{(4,5)}$ The finding of atheromatous plaques on carotid ultrasound is more relevant than the presence of hemodynamic changes. ${ }^{(4)}$

In CRVO, the most common treatments are intravitreal injection of anti-VEGF, such as ranibizumab and aflibercept, or intravitreal dexamethasone implant, such as Ozurdex $^{\circledR}$. All of those treatments are approved by Food and Drug Administration (FDA). ${ }^{(14)}$ Ozurdex $^{\circledR}$ was chosen in this case since it seems to have significant beneficial effects in improving venous engorgement, retinal hemorrhage and disc swelling. ${ }^{(9,15)}$

Considering most negative ancillary tests and presence of bilateral atheroma in carotid arteries, we believe the bilateral ocular findings of our patient were probably a consequence of non-controlled comorbidities, such as hypertension and dyslipidemia. Also, it is important to emphasize the patient is also at risk for ischemic events after treatment, largely because atherosclerotic disease is the primary underlying diagnosis of his condition. ${ }^{(1)}$

\section{REFERENCES}

1. Chawluk JB, Kushner MJ, Bank WJ, Silver FL, Jamieson DG, Bosley TM, et al. Atherosclerotic carotid artery disease in patients with retinal ischemic syndromes. Neurology. 1988;38(6):858-63.

2. Kang EY, Lin YH, Wang NK, Yeung L, Luo C, Wu WC, et al. Aspirin use in central retinal arterial occlusion to prevent ischaemic stroke: a retrospective cohort study in Taiwan. BMJ Open. 2019;9(2):e025455.
3. Mir TA, Arham AZ, Fang W, Alqahtani F, Alkhouli M, Gallo J, et al. Acute vascular ischemic events in patients with central retinal artery occlusion in the United States: A Nationwide Study 2003-2014. Am J Ophthalmol. 2019;200:179-86.

4. Patel SP, Sadda SR. Retinal artery occlusions. In: Schachat AP, Wilkinson CP, Hinton DR, Sadda SR, Wiedemann P. Ryan's retina. 6th ed. London: Elsevier; 2018. Cap. 54, p. 3445-89.

5. Hayreh SS. Central retinal artery occlusion. Indian J Ophthalmol. 2018;66(12):1684-94.

6. Oellers $P$, Halm P, Fekrat S. Central retinal vein occlusion. In: Schachat AP, Wilkinson CP, Hinton DR, Sadda SR, Wiedemann P. Ryan's retina. 6th ed. London: Elsevier; 2018. Cap. 57, p. 3536-79.

7. Hayreh SS. Ocular vascular occlusive disorders: natural history of visual outcome. Prog Retin Eye Res. 2014;41:1-25.

8. Graefes A. Ueber Embolie der Arteria centralis retinae als Ursache plotzlicher Erblindung. Arch Ophthalmol. 1859;5:136-57.

9. Choi EY, Kang HG, Lee SC, Kim M. Intravitreal dexamethasone implant for central retinal vein occlusion without macular edema. BMC Ophthalmol. 2019;19(1):92.

10. Kang EY, Lin YH, Wang NK, Yeung L, Luo C, Wu WC, et al. Aspirin use in central retinal arterial occlusion to prevent ischaemic stroke: a retrospective cohort study in Taiwan. BMJ Open. 2019;9(2):e025455.

11. Chen CS, Lee AW, Campbell B, Lee T, Paine M, Fraser C, et al. Efficacy of intravenous tissue-type plasminogen activator in central retinal artery occlusion: report from a randomized, controlled trial. Stroke. 2011;42(8):2229-34

12. Schmidt D. Comorbidities in combined retinal artery and vein occlusions. Eur J Med Res. 2013;18(1):27.

13. Chang IB, Lee JH, Kim HW. Combined central retinal vein and artery occlusion in a patient with elevated level of factor VIII: a case report. Int Med Case Rep J. 2019;12:309-12.

14. Lashay A, Riazi-Esfahani H, Mirghorbani M, Yaseri M. Intravitreal medications for retinal vein occlusion: systematic review and metaanalysis. J Ophthalmic Vis Res. 2019;14(3):336-66.

15. Kewcharoen J, Tom ES, Wiboonchutikula C, Trongtorsak A, Wittayalikit C, Vutthikraivit $W$, et al. Prevalence of Atrial Fibrillation in Patients with Retinal Vessel Occlusion and Its Association: A Systematic Review and Meta-Analysis. Curr Eye Res. 2019;44(12):1337-44. 